\title{
Problems with classification of spa waters used in balneology
}

\author{
Csaba Varga
}

Department of Environmental Health, University of Pécs, Pécs, Hungary; chemsafety@,freemail.hu.

Received 14 September 2010; revised 25 September 2010; accepted 30 September 2010.

\begin{abstract}
Recently, several measurements have indicated the presence of biologically active organic micropollutants or trace components in different types of waters, including spa and medicinal waters. The wide spectrum and abundance of organic components of spa waters in the Carpathian basin and other European regions has been demonstrated by gas-chromatographic analyses. These components may have main role in the therapeutic and preventive mechanisms. Considering the new analytical data, traditional European classification of spa waters based on the quality and quantity of inorganic ions (salts) should be reevaluated. The association of inorganic components and the therapeutic effects is also necessary to reconsider.
\end{abstract}

Keywords: Spa Water; Medicinal Water; Classification; Organic Compounds; Balneotherapy; Prevention

\section{INTRODUCTION AND AN HISTORICAL BACKGROUND}

Therapeutic use of spa (thermal) waters has been a part of the cultural and medical traditions of the European and especially the Central European (CE) nations. Frequent visits of middle-class people and the aristocracy at the famous spas were social events, as well. That is why successor countries of the former German Empire, Italy and Austro-Hungarian Monarchy have preserved this unique culture and their scientists are overrepresented in balneological science and mineral water chemistry, even today.

In spite of the expansive research, we are not aware of the exact mode of action of the different spa waters. Only few countries have specific regulations or acts in this field. Based upon the regulations of CE countries (e.g. Hungary, Slovakia, and Romania) a simple analytical study is enough for qualification as "mineral water" [13]. However, medical observation is also needed for qualification as "medicinal water", that is, a specific therapeutic effect should be proved in a comparative study, by using treated and placebo groups of patients [3-5]. Its exact way is to perform a double or triple blind (interventional) epidemiological study [6-8]. In brief: the law in the $\mathrm{CE}$ countries declares that medicinal waters should be mineral waters, but mineral waters are not definitely medicinal ones.

\section{INORGANIC COMPOUNDS}

The effects of spa waters were already well-known in the $16^{\text {th }}$ century [9]. At the turn of the 20th century, a series of scientific books mapped the most important spas in the Carpathian Basin (Hungarian Kingdom) from the Highland (recently Slovakia) to Transylvania (recently Romania) from point of view of geology, chemistry and therapeutic effects $[10,11]$. The inorganic analysis of waters has been performed accurately since the $18^{\text {th }}-19^{\text {th }}$ centuries, therefore their medical effects have also been tried to explain with the salt content. Traditionally, medicinal (or healing) waters in the European literature are categorized into the following groups $[12,13]$ indicated in Table 1.

The healing effects of balneotherapy in wide range of diseases are well described [14], however, exact mechanism of the healing spa cure is completely unknown, at least its relationship to the presence of certain chemical ingredients. The well-known physical (thermal, mechanical) features affect the circulation and locomotor organs (disorders). But same effects can also be detected using simple hot water as a consequence of the similar hydrostatic and thermal circumstances.

The chemical effects may be caused by the substances forming real aqueous solutions or colloidal systems. Their absorption takes place through the skin, or in case of volatiles, by inhalation. The classical theory tries to explain the therapeutic efficiency exclusively with the presence of inorganic ions (salts) and gases. That is why 
Table 1. Classification of medicinal waters (modified Papp's system).

\begin{tabular}{|c|c|}
\hline Category & Main features \\
\hline Simple thermal waters & $\geq 25^{\circ} \mathrm{C}$ \\
\hline $\begin{array}{l}\text { Simple acidic (carbonized) } \\
\text { waters }\end{array}$ & $\geq 1 \mathrm{~g} / \mathrm{L}$ free $\mathrm{CO}_{2}$ \\
\hline $\begin{array}{l}\text { Alkaline (Na-K-bicarbonated) } \\
\text { waters }\end{array}$ & $\begin{array}{l}\geq 1 \mathrm{~g} / \mathrm{L} \text { total dissolved solid, } \\
\text { dominant anion: } \mathrm{HCO}_{3}^{-}\end{array}$ \\
\hline Ca-Mg-bicarbonated waters & $\begin{array}{l}\geq 1 \mathrm{~g} / \mathrm{L} \text { total dissolved solid, } \\
\text { dominant cations: } \mathrm{Ca}^{2+}, \mathrm{Mg}^{2+} \\
\text { dominant anion: } \mathrm{HCO}_{3}{ }^{-}\end{array}$ \\
\hline Chloridated (saline) waters & $\begin{array}{l}\geq 1 \mathrm{~g} / \mathrm{L} \text { total dissolved solid, } \\
\text { dominant cation: } \mathrm{Na}^{+} \\
\text {dominant anion: } \mathrm{Cl}^{-}\end{array}$ \\
\hline Ironic (ferrous) waters & $\geq 10 \mathrm{mg} / \mathrm{LFe}^{2+}$ or $\mathrm{Fe}^{3+}$ \\
\hline Sulphuric waters & $\begin{array}{l}\text { Total sulphur } \geq 1 \mathrm{mg} / \mathrm{L}\left(\mathrm{HS}^{-} \text {or }\right. \\
\left.\mathrm{S}_{2} \mathrm{O}_{3}{ }^{2-} \text { or } \mathrm{S}^{2-} \text { or } \mathrm{H}_{2} \mathrm{~S}\right)\end{array}$ \\
\hline Sulphated waters & $\begin{array}{l}\geq 1 \mathrm{~g} / \mathrm{L} \text { total dissolved solid, } \\
\text { dominant anion: } \mathrm{SO}_{4}{ }^{2-}\end{array}$ \\
\hline Iodated-bromidated waters & $\geq 1 \mathrm{mg} / \mathrm{L} \mathrm{I}^{-}$or $\geq 5 \mathrm{mg} / \mathrm{L} \mathrm{Br}^{-}$ \\
\hline Radioactive waters & Radon or toron content \\
\hline
\end{tabular}

the presently used classification of spa waters are based on the inorganic contents.

\section{FACTS AND ARGUMENTS FOR THE POSSIBLE ROLE OF ORGANICS}

The basic problem of balneology (balneotherapy, balneoprevention) can be outlined with a simple formal logical approach. If $\mathbf{A}$ contains $\mathbf{B}$ too (that is the spa water contains salts too) and $\mathbf{A}$ cures $\mathbf{C}$ (that is water is effective in some diseases), it does not mean that $\mathbf{B}$ cures $\mathbf{C}$. Therefore not definitely the salts which are effective in the water, since other components are (may be) also present in it, not just salts. In this study we try to collect the direct and indirect evidences for an unconventional explanation on the mode of action of spa waters used in prevention and therapy.

\subsection{Why Medical Trial is Necessary for Qualification of Spa Water as "Medicinal Water"?}

Because, the exact inorganic analytical study cannot predict the therapeutic efficiency. We have no exact data whether redissolution of the total salt content in distilled water can recover the therapeutic effects. Sometimes, even the complete redissolution of salts is impossible without residuals.

\subsection{All Known Medicinal Water Contain Organic Fraction}

Results of science and practice of organic water analy- tics cannot be neglected by balneology, either. Recently, several measurements have indicated the presence of biologically active organic micropollutants or trace components in different types of waters, especially in disinfected drinking waters $[15,16]$. Observed concentrations are very low: $\mathrm{pg} / \mathrm{L}, \mathrm{ng} / \mathrm{L}$ or $\mu \mathrm{g} / \mathrm{L}$, but biologically active compounds may have stochastic effects without threshold dose. The wide range of organic components of spa waters in the Carpathian Basin [17] and other European regions $[18,19]$ is also demonstrated by the state-of-art analytical methods. Hot spring or deep artesian well waters may contain many identified and unidentified compounds from the simple aliphatic through the simple aromatic hydrocarbons to the heteroaromatics and sophisticated polycyclic aromatic compounds. A simple gas-chromatogram can characterize the unique spa water or its springs and wells, like a fingerprint [20-22] (Figure 1). These components either may have main role in the therapeutic mechanism or/and probable toxicity [23].

\subsection{Biological Activities}

Even biological activities of the single aquatic organic compounds are not known, but we are not aware of their possible interactions, in particular. At least one biologically active organic compound has, however, been wellknown for a long while. Water and mud of some Hun-
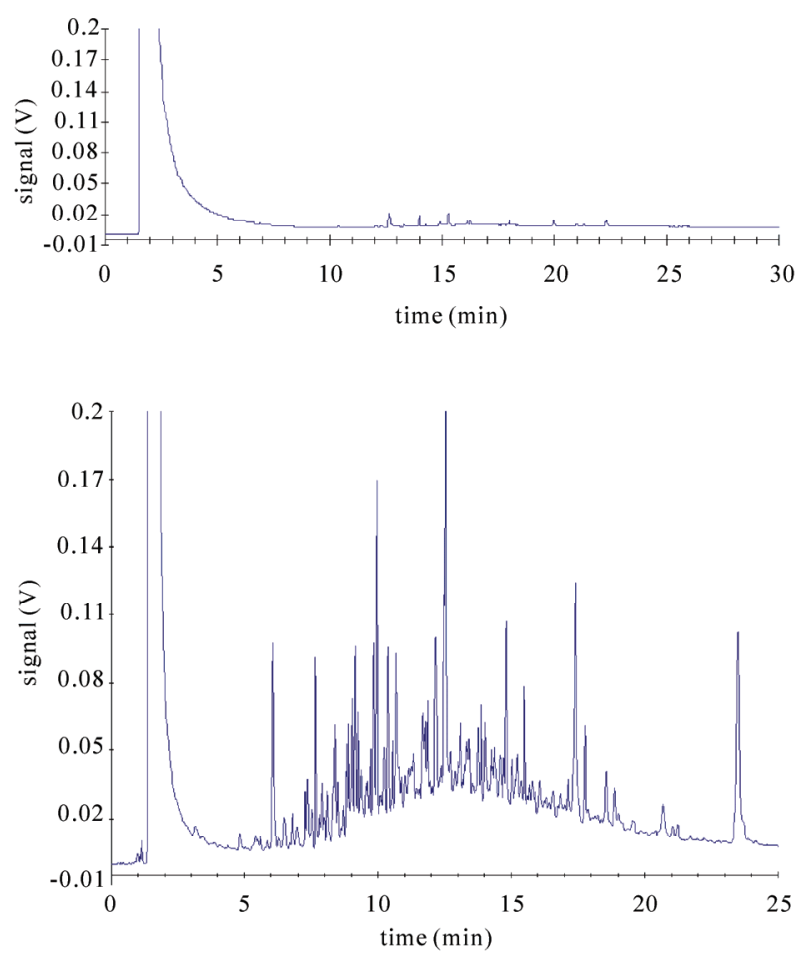

Figure 1. Gas-chromatogram of a drinking water sample (up) and a Hungarian medicinal water sample (Hajdúszoboszló) (down). (Etanol extraction, temperature programming, FID). 
garian spas contain natural estrogens of geochemical origin and are highly effective in gynecological postoperative states and disorders [12]. In this case, salt quality and concentration is probably indifferent.

\subsection{Dissolution and Absorption}

Organic fraction can also promote dissolution of inorganic compounds and their absorption into the human body. Therefore, modeling of absorption using inorganic isotopes alone is not valid if the organic complexes promote this process.

\subsection{Blood Analyses}

Chemical analysis of patients' blood samples for the 4 main cations could not show any evidence of absorption during bathing in spa waters. A Hungarian study suggests that the main inorganic cations $\left(\mathrm{Na}^{+}, \mathrm{K}^{+}, \mathrm{Ca}^{2+}, \mathrm{Mg}^{2+}\right)$ cannot have any effect, if they are absorbed at all, because their concentrations in the human body is higher with several order of magnitude [24].

\subsection{Mode of Action}

Organic fractions of medicinal waters may have crucial issue in the mode of action. Considering the new analytical data, traditional classification of spa waters based upon the quality and quantity of inorganic ions (salts) should be revaluated. The relationship of inorganic components and the therapeutic effects is also necessary to reconsider, excepting some specific waters used in drinking cures (sulphated, alkaline, fluoridated, iodated waters).

\subsection{Importance of Inorganic Analyses}

The presence of the inorganic components and not least the $\mathrm{pH}$, however, can strongly affect the hydrophilic and hydrophobic characteristics of organics, inhibiting or promoting the absorption. Therefore inorganic analyses are also crucial in assessment of the possible effects.

\section{CONCLUSION}

Spa (medicinal) waters should be reclassified in the scientific literature related to their therapeutic and preventive characteristics. The new categories should also be based upon the state-of-art methodological armament of water analytics and therapeutic evidences, meeting requirements of the $21^{\text {st }}$ century. At present, we have limited data to establish such a new system due to the lack of organic analyses. Complete set of data needs to be registered in case of medicinal waters, involving determination of all chemical (inorganic and organic), geo-physical, hydrobiological, microbiological and toxicological parameters, representing the particular medicinal water. Quality assurance of therapeutic elements should also be in close correlation with the parameters mentioned above.

On the other hand, a new logical possibility should be ruled. Namely, if the therapeutic efficiency of particular water is caused by organic compound(s), mineral content as a necessary condition is not a valid parameter for "medicinal water" qualification $[25,26]$. The chance for the absence of the necessary salt concentration-required by the acts - in medicinal waters is actually very little, but cannot be excluded theoretically. This logical conclusion should be accepted by the regulatory authorities, as well.

\section{ACKNOWLEDGEMENT}

This work was supported by the Faculty of Medicine, University of Pécs (grant No. 34039).

\section{REFERENCES}

[1] 65/2004 FVM-ESzCsM-GKM [Hungary] on mineral waters.

[2] Legea apelor [Romania] (LEGE nr.107 din 25 September 1996)

[3] Prirodná minerálna voda, pramentá voda a balená voda [Slovakia] http://www.svssr.sk/sk/legislativa/kodex/3 28 04.pdf

[4] 74/1999. EüM [Hungary] on the natural healing factors.

[5] Domahidi, J., Csiszér, A., Buksa, C., Jeszenszky, K., Tarcea, M., Butiurca, Z., Menyhárt, E., Oroian, M., Vitályos, O., Farcas, O., Palcu, C., Moldovan, S., Sandru, A. and Varga, C. (2009) Monitoring of mineral waters for the cure in Mures County. International Journal of Hygiene and Environmental Health, 59(1), 97-106.

[6] Szucs, L., Ratko, I., Lesko, T., Szoor, I., Genti, G. and Balint, G. (1989) Double-blind trial on the effectiveness of the Puspokladany thermal water on arthrosis of the knee-joints. Royal Society of Health Journal, 109(1), 7-9.

[7] Konrad, K., Tatrai, T., Hunka, A., Vereckei, E. and Korondi, I. (1992) Controlled trial of balneotherapy in treatment of low back pain. Annals of the Rheumatic Diseases, 51(6), 820-822.

[8] Kovacs, I. and Bender, T. (2002) The therapeutic effects of Cserkeszolo thermal water in osteoarthritis of the knee: a double blind, controlled, follow-up study. Rheumatology International, 2, 218-221.

[9] Werner, G. (1549) De amirandis Hungariae aquis hypomnemation. Basel.

[10] Preysz, K. (1892-1910) Balneological library. Hungarian spas. Budapest-Vienna.

[11] Hintz, H. (1901) Bártfa healing spa in Sáros County (Bártfa gyógyfürdő Sáros vármegyében). Budapest, 1-126.

[12] Papp, S. (1957) Chemical characteristics of mineral and medicinal waters. In: Schulhof, Ö. Ed., Mineral and medicinal waters of Hungary. (Magyarország ásvány és gyógy-vizei, Akadémiai, Budapest, 337-632.

[13] Schulhof, Ö. (1976) Balneotherapia. In: Bozsóky, S. and 
Irányi, J. Eds., Physiotherapia, Medicina, Budapest, 225259.

[14] Nasermoaddeli, A. and Kagamimori, S. (2005) Balneotherapy in medicine: A review. Environmental Health and Preventive Medicine, 10(4), 171-179.

[15] IARC (1991) Monographs on the evaluation of carcinogenic risks to humans. 52. Chlorinated drinking water. IARC, Lyon, 1-359.

[16] IARC (2004) Monographs on the evaluation of carcinogenic risks to humans. 84 . Some drinking water disinfectants and contaminants, including arsenic. IARC, Lyon, 1-512.

[17] Kárpáti, Z., Sajgó, C., Vető, I., Klopp, G. and Horváth, I. (1999) Organic matter in thermal waters of the Pannonian Basin - A preliminary report on aromatic compounds. Organic Geochemistry, 30, 701-712.

[18] DiGioia, M.L., Leggio, A., LePera, A., Liguori, A. and Perri, A. (2006) Occurrence of organic compounds in the thermal sulphurous waters of Calabria, Italy. Chromatographia, 63(11-12), 585-590.

[19] Gonzales-Barreiro, C., Cancho-Grande, B., Araujo-Nespereira, P., Cid-Fernández, J.A. and Simal-Gándara, J. (2009) Occurrence of soluble organic compounds in thermal waters by ion trap mass detection. Chemosphere, $\mathbf{7 5}$, 34-47.
[20] Varga, C. and Domahidi, J. (2009) Preventive chemical and toxicological investigations of medicinal waters and muds in Hungary and Transylvania. Hungarian Epidemiology, 7(1), S113-114.

[21] Varga, C., Szuetta, J., Gerencsér, G., Csiszér, A. and Domahidi, J. (2009) Possible role and effects of organic compounds in spa waters. Proceedings of Scientific Congress of FEMTEC, Yokohama, 8-12 November 2009, 72-73.

[22] Varga, C. and Szuetta, J. (2008) Balneoprevention. ISMH Congress, Porto.

[23] Gerencsér, G., Szendi, K., Murányi, E. and Varga, C. (2010) Ecotoxicological studies on Hungarian peloids (medicinal muds). Applied Clay Science, 50, 47-50

[24] Szuetta, J. and Pap, L. (2007) Human biological studies with Hungarian medicinal waters. Course on mineral and spa waters. Balneology, Faculty of Medicine, University of Pécs. http://www.pote.hu/pubhealth/balneology

[25] Gutenbrunner, C., Bender, T., Cantista, P. and Karagülle, Z. (2010) A proposal for a worldwide definition of health resort medicine, balneology, medical hydrology and climatology. International Journal of Biometeorology, 54(5), 495-507.

[26] Varga, C. (2010) The Balneology paradox. International Journal of Biometeorology, article appeared online: DOI: 10.1007/s00484-010-0378-1. 